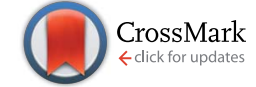

Cite this: RSC Adv., 2017, 7, 14247

Received 23rd December 2016 Accepted 26th February 2017

DOI: $10.1039 / c 6 r a 28603 h$

rsc.li/rsc-advances

\section{A zeolite modified carbon paste electrode based on copper exchanged clinoptilolite nanoparticles for voltammetric determination of metronidazole $\uparrow$}

\author{
Elahe Shahnazari-Shahrezaie ${ }^{\text {ab }}$ and Alireza Nezamzadeh-Ejhiehªbc \\ A simple and effective zeolite modified electrode (ZME) was constructed from $\mathrm{Cu}(\Perp)$-exchanged \\ clinoptilolite nanoparticles (CU(॥)-CNP). The modifier was characterized by FTIR, BET, XRD and TEM \\ techniques. The modified carbon paste electrode (CU(I)-CNP/CPE) was used for the voltammetric \\ determination of metronidazole (MNZ). The best voltammetric response was obtained by the electrode \\ containing $20 \%$ of the modifier in $\mathrm{NaCl} 0.4 \mathrm{~mol} \mathrm{~L}^{-1}$ at $\mathrm{pH}$. The electrode showed a linear response in \\ the concentration range of $2.0 \times 10^{-8}$ to $1.6 \times 10^{-6} \mathrm{~mol} \mathrm{L^{-1 }} \mathrm{MNZ}$ with a detection limit of $4.1 \times$ \\ $10^{-9} \mathrm{~mol} \mathrm{~L}^{-1}$ from square wave voltammetry. The electrode showed good repeatability, reproducibility, \\ and a long lifetime based on statistical tests. The electrode also has good selectivity and good \\ applicability in the determination of MNZ in some pharmaceutical samples.
}

\section{Introduction}

Metronidazole (MNZ), with a broad spectrum of activity against parasitic and bacterial infections and widely use for the treatment of different diseases (trichomonas, giardias, Vincent's organisms, anaerobic bacteria and amebiasis) can cause cancer in animals. Although, there is not enough evidence to confirm its carcinogenic effect on humans, MNZ is banned from veterinary use in the feed of animals. ${ }^{1-3}$ Accordingly, developing novel methods for the determination of low levels of MNZ is very important in food security, human health and the study of biological toxicity of MNZ. Among the different spectrophotometric, chromatographic and electrochemical methods used for the determination of $\mathrm{MNZ}^{\mathbf{4 - 7}}$ electrochemical methods are more famous due to their lower cost, higher sensitivity and faster response than other methods. Nevertheless, the nitro group of $\mathrm{MNZ}$, as an electroactive reducible center, has shown poor reproducibility and sensitivity at the bare electrodes. ${ }^{8}$ In general, modification of electrode surfaces with suitable modifier overcomes to such problems. In recent decades, zeolite-modified electrodes (ZMEs) have been widely used in determination of different organic, inorganic and pharmaceutical compounds. The ZMEs, compared to other chemically-modified electrodes,

${ }^{a}$ Department of Chemistry, Shahreza Branch, Islamic Azad University, P.O. Box 311-86145, Shahreza, Isfahan, Iran. E-mail: arnezamzadeh@iaush.ac.ir; Fax: +98 31 53291018; Tel: +98 3153292515

${ }^{b}$ Young Researchers and Elite Club, Shahreza Branch, Islamic Azad University, Shahreza, Iran

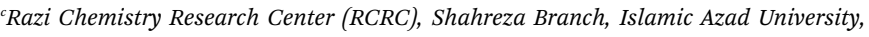
Isfahan, Iran. Tel: +983153292500

$\dagger$ Electronic supplementary information (ESI) available. See DOI: 10.1039/c6ra28603h have the unique size, shape and charge selectivity, due to molecular sieve property of zeolites, with a high cation-exchange capacity (CEC). ${ }^{9-13}$ High CEC of zeolites permit to load some transition metals with catalytic property into the zeolite for using them in electrocatalytical purpose.

In this work, ball-mill clinoptilolite nanoparticles (CNPs) were ion exchanged in $\mathrm{Cu}$ (II) aqueous solution and the obtained $\mathrm{Cu}(\mathrm{II})$ CNP was used for modification of carbon paste electrode (CPE). The prepared $\mathrm{Cu}$ (II)-CNP/CPE was then used for voltammetric determination of MNZ. Effect of some key operating parameters on the electrode response was studied and optimized.

\section{Experimental}

\subsection{Reagents, preparation and solutions}

All chemicals were analytical grade from Merck chemical company and used without further purification. Metronidazole (Batch no. = TM2012127) was purchased from Zhonghan Tianhin Company. Natural Iranian clinoptilolite (Semnan region in the north-east of Iran) was purchased from Afrandtooska Company (Iran). Typical procedure for preparation of and pretreatment of CNPs for removing magnetic and water soluble impurities was illustrated in our previous work. ${ }^{\mathbf{1 1}}$

All solutions were prepared in triply distilled water. Stock solutions of $0.005 \mathrm{~mol} \mathrm{~L}^{-1} \mathrm{MNZ}$ were freshly prepared in water. MNZ pharmaceutical tablets $(250 \mathrm{mg})$ were purchased from Amin, Tehran Chemie, Abidie, Alborz Companies (Iran). Adequate amount of each tablet was well powdered and dissolved in water. The solution was filtered and diluted with water in volumetric flask.

To prepare $\mathrm{Cu}(\mathrm{II})$-CNP, $1 \mathrm{~g}$ of $\mathrm{CNP}$ was added to $25 \mathrm{~mL} 0.1$, $0.25,0.4,0.5,0.6,0.8$ and $1.0 \mathrm{~mol} \mathrm{~L}^{-1} \mathrm{CuSO}_{4}$ solutions. The 
resulted suspensions were shaken on a magnetic stirrer for 12 . This was repeated two times to complete ion exchange process and finally centrifuged at $6000 \mathrm{rpm}$. The filtrate was resuspended in $2 \% \mathrm{HCl}$ solution to remove adhered impurities. Typical procedure for digestion of $\mathrm{Cu}(\mathrm{II})-\mathrm{CNP}$ by $\mathrm{HF}+\mathrm{HClO}_{4}+$ $\mathrm{HNO}_{3}$ for atomic spectroscopic determination of $\mathrm{Cu}(\mathrm{II})$ was illustrated in our previous work. ${ }^{11}$

Typical procedure for preparation of the raw and modified CPEs using insulin syringe was illustrated in our previous work. ${ }^{11}$ The electrode surface was smoothed on a piece of weighing paper and after using it was regenerated by pushing an excess of paste out of the tube, removing the excess, and polishing again mechanically the electrode surface.

For preparation of real samples (tablet, vaginal suppository and ampoule) applied as follows. (A) Each $250 \mathrm{mg}$ metronidazole tablet (obtained from Amin, Abidi, Alborz daru and Tehran Shimi companies, Iran) was dissolved in water and filtered in $250 \mathrm{~mL}$ volumetric flask. (B) Metronidazole ampoule was diluted 10 folds and used. (C) $5 \mathrm{~g}$ of vaginal gel was dissolved in $50 \mathrm{~mL}$ water and filtered in $250 \mathrm{~mL}$ volumetric flask. In voltammetric measurements aliquots of each samples was added to the voltammetric cell to achieve desired concentration.

\subsection{Apparatus}

XRD Bruker diffractometer (D8 Advance, Ni-filtered copper radiation at $\mathrm{K}_{\alpha}=1.5406 \AA$ ), Transmission Electron Microscope S-3500 N with Absorbed Electron Detector S-6542 (Hitachi Science System Ltd) and BET (Belsorp Adsorption/Aesorption Data Analysis Software, Japan) are the instruments were used for characterization of samples. The electrochemical experiments were performed with an Autolab PGSTAT101 (Netherland). All voltammograms were recorded with a three-electrode system including an $\mathrm{Ag} / \mathrm{AgCl}$ (containing $3.5 \mathrm{~mol} \mathrm{~L}^{-1} \mathrm{KCl}$ ) reference electrode, a platinum wire as the counter electrode, and the $\mathrm{Cu}(\mathrm{II})-\mathrm{CNP} / \mathrm{CPE}$ as working electrode. The $\mathrm{pH}$ of solutions was adjusted using a digital pH meter (Jenway 370).

\subsection{Voltammetric experiments}

Adequate volume of the standard or the measuring MNZ solution was added into voltammetric cell containing $20 \mathrm{~mL}$ of $\mathrm{NaCl}$ (0.4 $\mathrm{mol} \mathrm{L}^{-1}$ ) as the supporting electrolyte and immediately used after deaerated with $\mathrm{N}_{2}$ for $5 \mathrm{~min}$. The modified electrode, the reference and the counter electrodes were immersed into the measuring solution and $\mathrm{CV}$ voltammograms were recorded in the range of 0 to $-1 \mathrm{~V} v s$. $\mathrm{Ag} / \mathrm{AgCl}$, while $\mathrm{N}_{2}$ was passed over the test solutions. The modified electrode was kept in open air when not in use.

\section{Results and discussion}

\subsection{Characterizations studies}

The X-ray diffraction (XRD) pattern of the used zeolite nanoparticles is shown in Fig. 1A. This pattern showed good agreement with crystallite data of clinoptilolite (JCPDS no. 39-1383) and hence the most important $h k l$ planes of clinoptilolite were assigned in the pattern. ${ }^{14}$ Average crystallite size of the raw CNP was estimated about $37 \mathrm{~nm}$ by using the Scherrer equation. ${ }^{15}$ To confirm that nano dimension of zeolite retained after ion exchange process, TEM image of $\mathrm{Cu}(\mathrm{II})$-CNP was recorded and particles size distribution was estimated by applying the image-j software. As shown in Fig. 1B average size of $\mathrm{Cu}(\mathrm{II})-\mathrm{CNP}$ was about $46 \mathrm{~nm}$.

The Brunauer-Emmett-Teller (BET) method was used to study of surface properties of the modified CNP sample which of results are shown in Fig. 1C. By using the BET equation
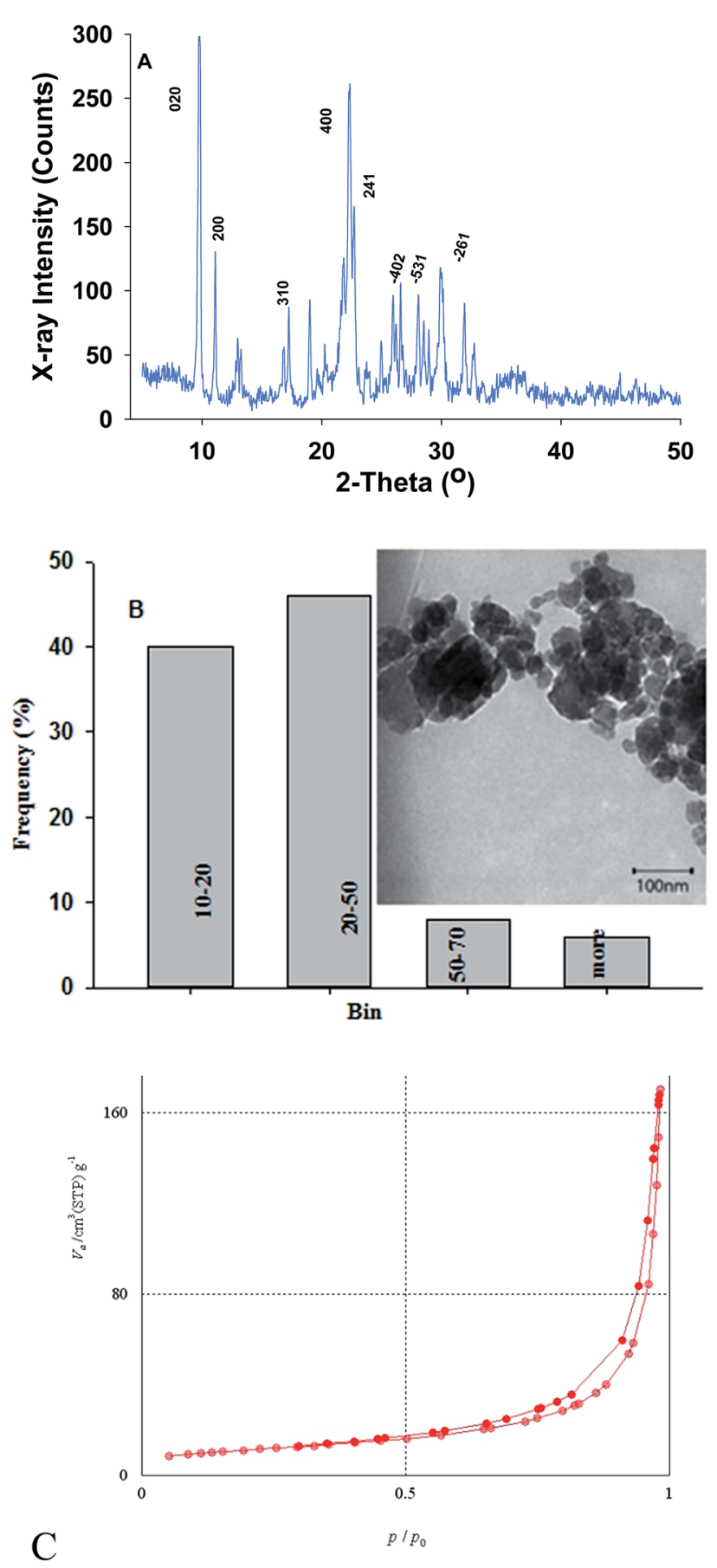

Fig. 1 (A) XRD pattern of parent CNP; (B) particles size distribution of the raw CNP (inset: TEM image); (C) adsorption/desorption plot of the modified CNP (Cu(॥) $0.5^{-}$CNP). 
Table 1 Abbreviations of the modified samples and their loaded $\mathrm{Cu}(\mathrm{II})$

\begin{tabular}{lll}
\hline Sam. abbreviation & $\begin{array}{l}C_{\mathrm{Cu}} \\
\left.\text { (ion exch. sol.: } \mathrm{mol} \mathrm{L}^{-1}\right)\end{array}$ & $\begin{array}{l}\text { Loaded Cu } \\
\left(\mathrm{meq} \mathrm{g}^{-1}\right)\end{array}$ \\
\hline $\mathrm{Cu}(\mathrm{II})_{0.1}$-CNP & 0.10 & 0.25 \\
$\mathrm{Cu}(\mathrm{II})_{0.25}-\mathrm{CNP}$ & 0.25 & 0.73 \\
$\mathrm{Cu}(\mathrm{II})_{0.4}$-CNP & 0.40 & 1.23 \\
$\mathrm{Cu}(\mathrm{II})_{0.5}-\mathrm{CNP}$ & 0.50 & 1.73 \\
$\mathrm{Cu}(\mathrm{II})_{0.6}-\mathrm{CNP}$ & 0.60 & 1.51
\end{tabular}

surface properties of the samples were estimated from isotherms, which are in accordance with type III according to the IUPAC's rules for the mesoporous structures. ${ }^{16}$ Comparison of the results with the obtained results for the raw CNP reported in our previous work, ${ }^{11}$ confirms that $S_{\mathrm{BET}}\left(49.0 \mathrm{~cm}^{2} \mathrm{~g}^{-1}\right), V_{\mathrm{p}}$ $\left(3.94 \mathrm{~cm}^{3} \mathrm{~g}^{-1}\right)$ and $d_{\mathrm{p}}(28.3 \mathrm{~nm})$ of the raw CNP were changed to $39.7 \mathrm{~cm}^{2} \mathrm{~g}^{-1}, 2.6 \mathrm{~cm}^{3} \mathrm{~g}^{-1}$ and $32.8 \mathrm{~nm}$ in the $\mathrm{Cu}(\mathrm{II})$-CNP sample, respectively.

The modified CNPs prepared by ion exchanging in solutions containing different $\mathrm{Cu}(\mathrm{II})$ concentrations ranging from 0.1 to $0.6 \mathrm{~mol} \mathrm{~L}^{-1}$ were analyzed by atomic absorption spectroscopy and the corresponding results are summarized in Table 1. Effect of concentration on ion exchange extent of zeolite has illustrated in literature. ${ }^{17}$ As shown later, the modified CNP prepared in $0.5 \mathrm{~mol} \mathrm{~L}^{-1} \mathrm{Cu}(\mathrm{II})$ solution showed the best voltammetric response and hence it has used in all above characterization techniques.

\subsection{Voltammetric measurements}

3.2.1. Effect of modification, and other preliminary species. $\mathrm{CV}$ voltammograms of the raw $\mathrm{CPE}$ and $\mathrm{Cu}(\mathrm{II})-\mathrm{CNP} / \mathrm{CPE}$ electrodes in $\mathrm{NaCl}$ supporting electrolyte solution in the absence and presence of MNZ are shown in Fig. 2A. CPE and $\mathrm{CNP} / \mathrm{CPE}$ (CVs is not shown) have no voltammetric current in supporting electrolyte, because no electroactive species are present in electrode-solution interface at the applied conditions. ${ }^{18}$ In opposite, the modified $\mathrm{Cu}(\mathrm{II})$-CNP/CPE electrode showed considerable peak currents in the absence and presence of MNZ.

In case of $\mathrm{Cu}(\mathrm{II})-\mathrm{CNP} / \mathrm{CPE}$ in $\mathrm{NaCl}$ solution, according to eqn (1), ion exchange between $\mathrm{Na}(\mathrm{I})$ cations in supporting electrolyte and $\mathrm{Cu}$ (II) cations in the modified zeolite present in CPE, brings $\mathrm{Cu}$ (II) cations at the electrode surface. These cations undergo reduction reactions according to reactions (2) and (3). The first reduction begun at $0.304 \mathrm{~V}$ and continue till $-0.371 \mathrm{~V}$. This reaction show no sharp peak because $\mathrm{Cu}$ (II) cations exit from zeolite holes gradually. Produced $\mathrm{Cu}(\mathrm{I})$ in reaction (2) can be reduced at more negative potentials $(-0.382 \mathrm{~V})$ to metallic $\mathrm{Cu}$.

By addition of MNZ to the solution, peak currents especially the cathodic one increased and hence this change was followed in the next studies. We suggest following phenomena to illustrate our observations. In the first alternative, $\mathrm{Cu}(\mathrm{I})$ cations in the electrode-solution interface form a complex with MNZ. On the other hand, produced $\mathrm{Cu}(\mathrm{I})$ cations in reaction (2) are instable and immediately form a complex with MNZ. This
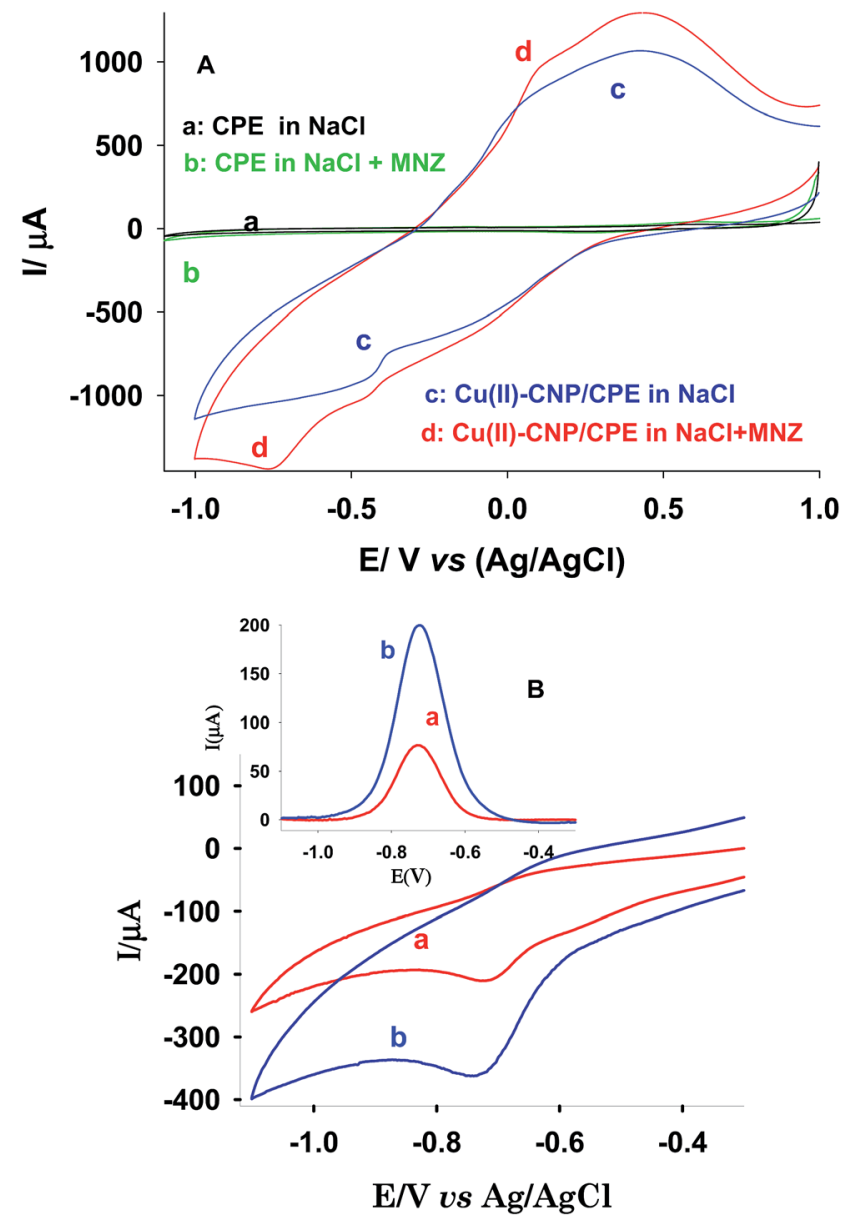

Fig. 2 (A) CVs of CPE (a and b) and Cu(॥) 0.5 - CNP/CPE (c and d, 10\% of the modifier) in $0.1 \mathrm{~mol} \mathrm{~L}^{-1} \mathrm{NaCl}$ solution in the absence and presence of MNZ (5 $\times 10^{-3} \mathrm{~mol} \mathrm{~L}^{-1}$ at $\left.\mathrm{pH} 5.5\right)$, scan rate: $60 \mathrm{mV} \mathrm{s}^{-1}$; (B) CVs and SqWs of (a) $\mathrm{Cu}\left({ }^{\prime}\right)_{0.1}-\mathrm{CMP} / \mathrm{CPE}$ and (b) $\mathrm{Cu}\left({ }_{0}\right)_{0.1}-\mathrm{CNP} / \mathrm{CPE}$ containing $10 \% \mathrm{~W}$ of the modifiers in $0.1 \mathrm{~mol} \mathrm{~L}^{-1} \mathrm{NaCl}$ and $5 \times 10^{-3} \mathrm{~mol} \mathrm{~L}^{-1} \mathrm{MNZ}$ solution ( $\mathrm{pH}$ 5.5), $\mathrm{CV}$ scan rate: $60 \mathrm{mV} \mathrm{s}^{-1}$, square wave conditions: step potential: $5 \mathrm{mV}$, amplitude: $55 \mathrm{mV}$, frequency: $25 \mathrm{~Hz}$.

process favors reactions (1) to (3) hence more $\mathrm{Cu}$ (II) cations reach in the electrode-solution interface. Hence, peak current resulted in reactions (2) and (3) belong to free $\mathrm{Cu}$ (II) and $\mathrm{Cu}(\mathrm{I})$ cations was increased. In addition, produced $\mathrm{Cu}(\mathrm{I})-\mathrm{MNZ}$ complex can be reduced at more negative potentials about $-0.385 \mathrm{~V}$ because complexed $\mathrm{Cu}(\mathrm{I})$ cations can be reduced more difficult than the free cations. In other alternative, metallic $\mathrm{Cu}$ adsorbs some $\mathrm{MNZ}$ molecules and form $\mathrm{Cu}-\mathrm{MNZ}$ complex. In the later step, the internal redox reaction occurs in this complex according to reaction (4). This can produce more $\mathrm{Cu}(\mathrm{I})$ species at the electrode-solution interface cause to higher oxidation current in the reverse scan.

$$
\begin{gathered}
\mathrm{Cu}(\mathrm{II})-\mathrm{CNP} / \mathrm{CPE}+2 \mathrm{Na}_{(\mathrm{s})}^{+} \leftrightarrow\left(\mathrm{Na}^{+}\right)_{2}-\mathrm{CNP} / \mathrm{CPE}+\mathrm{Cu}^{2+}{ }_{(\mathrm{i})} \\
\mathrm{Cu}^{2+}{ }_{(\mathrm{i})}+\mathrm{e}^{-} \leftrightarrow \mathrm{Cu}^{+}{ }_{(\mathrm{i})} \\
\mathrm{Cu}^{+}{ }_{(\mathrm{i})}+\mathrm{e}^{-} \leftrightarrow \mathrm{Cu}_{(\mathrm{i})}
\end{gathered}
$$




$$
\mathrm{Cu}-\mathrm{MNZ}_{(\mathrm{i})} \leftrightarrow \mathrm{Cu}(\mathrm{I})-\mathrm{MNZ}_{(\mathrm{i})}
$$

In these equations, descriptors $\mathrm{z}, \mathrm{s}$ and i stand for zeolite, solution, and zeolite-solution interface, respectively.

Effect of particle size of zeolite on the voltammetric behavior of the modified electrodes in the presence of MNZ was studied in $\mathrm{CV}$ and square wave voltammetric (SqW) techniques. The best performances obtained in SqW at step potential of $5 \mathrm{mV}$, amplitude $55 \mathrm{mV}$ and frequency $25 \mathrm{~Hz}$. Typical voltammograms in Fig. 2B shows significant increase in peak current in case of modified $\mathrm{CPE}$ with $\mathrm{Cu}(\mathrm{II})-\mathrm{CNP}$ and hence it was used in the next steps.

Effect of amount of loaded $\mathrm{Cu}$ (II) on the voltammetric response of the modified $\mathrm{Cu}$ (II)-CNP/CPE electrode in the presence of MNZ was studied (20\% modifier, $0.1 \mathrm{~mol} \mathrm{~L}^{-1} \mathrm{NaCl}+$ $0.005 \mathrm{~mol} \mathrm{~L}^{-1} \mathrm{MNZ}$ at $\mathrm{pH}$ 5.5). The $\mathrm{Cu}(\mathrm{II})$-CNP modifiers were obtained via ion exchanging of CNPs in $\mathrm{Cu}(\mathrm{II})$ solutions with different concentrations of $0.1,0.25,0.4$ and $0.5 \mathrm{~mol} \mathrm{~L}^{-1}$. The best voltammetric currents were obtained by the electrode that its modifier prepared in $0.5 \mathrm{~mol} \mathrm{~L}^{-1} \mathrm{Cu}(\mathrm{II})$ solution $\left(\mathrm{Cu}(\mathrm{II})_{0.5^{-}}\right.$ $\mathrm{CNP} / \mathrm{CPE}$ ) in both $\mathrm{CV}$ and SqW techniques (see SD1 in ESI data $\dagger$ ). Higher concentration of $\mathrm{Cu}$ (II) did not studied because of reducing of activity at higher concentrations. Hence this electrode was used in next studies.

Among the modified electrodes containing different dosages of the $\mathrm{Cu}(\mathrm{II})_{0.5}$-CNP modifier $(10,20,25$ and 30\%), the best peak currents obtained by the electrode containing $20 \%$ of the modifier (see SD2 in ESI data $\dagger$ ). At dosage below the optimum values low amounts of the modifier present in the electrode, while at higher dosages above the optimum value resistant of the modified electrode tend to increase, both resulting in peak current decrease.

The modified electrode containing $20 \%$ of the $\mathrm{Cu}(\mathrm{II})_{0.5}-\mathrm{CNP}$ modifier was then use to study of the effect of nature of the supporting electrolyte at the above mentioned conditions. Among the $0.1 \mathrm{~mol} \mathrm{~L}^{-1}$ of $\mathrm{KCl}, \mathrm{KNO}_{3}, \mathrm{MgCl}_{2}, \mathrm{CaCl}_{2}, \mathrm{NaCl}$ and $\mathrm{NaNO}_{3}$ supporting electrolytes, the best voltammetric peak current obtained in $\mathrm{NaCl}$ supporting electrolyte. Among the different concentrations of $\mathrm{NaCl}$ solutions covering the range from 0.1 to $0.5 \mathrm{~mol} \mathrm{~L}^{-1}$, the best voltammetric peak current obtained in $0.4 \mathrm{~mol} \mathrm{~L}^{-1} \mathrm{NaCl}$ solution (see SD3 and SD4 in ESI data $\dagger$ ). In general, ion exchange extent plays an important role in the voltammetric behavior of ZMEs. Ion exchange of ZMEs (and zeolites, in general) significantly depends to nature and concentration of supporting electrolyte, because size and charge density of the cations present in supporting electrolyte and the zeolite affect the ion exchange of zeolitic materials. ${ }^{9-13}$

3.2.2. Effect of scan rate. Effect of potential scan rate on the behavior of the modified $\mathrm{Cu}(\mathrm{II})_{0.5}-\mathrm{CNP} / \mathrm{CPE}$ (in the above optimized conditions) was studied in the absence and presence of MNZ. Typical CVs are presented in Fig. 3B and ESI data file (SD5 to $\mathrm{SD} 7 \dagger$ ). As shown, by increasing the potential scan rate to definite value (around $100 \mathrm{mV} \mathrm{s}^{-1}$ ) peak current was increased and thereafter decreased and clarity of the peaks significantly decreased. At low potential scan rates $\left(10,20 \mathrm{mV} \mathrm{s}^{-1}\right)$, located $\mathrm{Cu}(\mathrm{II})$ cations at the electrodes double layer via reaction (1) can diffuse to solution bulk before undergoing a redox reaction because potential is not enough. This causes to achieve small peak currents. Hence, increasing the potential scan rate to $70 \mathrm{mV} \mathrm{s}^{-1}$ provides potential enough to redox process of $\mathrm{Cu}$ (II) cations before they can diffuse to bulk solution. At higher potential scan rates than $100 \mathrm{mV} \mathrm{s}^{-1}$, although potential is enough for redox process of $\mathrm{Cu}(\mathrm{II})$ cations, but un-sufficient $\mathrm{Cu}$ (II) cations available at the electrode surface because of low rate of exiting $\mathrm{Cu}$ (II) cations from the zeolite surface. At higher scan rates than $150 \mathrm{mV} \mathrm{s}^{-1}$, clarity of the peaks is very low, so we cannot calculate peak current (see SD6†). According to the results, the best peak current was obtained at $70 \mathrm{mV} \mathrm{s}^{-1}$ as optimum value.

A linear relationship between $I_{\mathrm{p}}-\nu^{1 / 2}$ and $\log I_{\mathrm{p}}-\log \nu$ in potential scan rate from 10 to $80 \mathrm{mV} \mathrm{s}^{-1}$ was observed with equations of $y=7.5+0.7 .3 x\left(r^{2}=0.9831\right)$ and $y=0.65+0.58 x\left(r^{2}\right.$ $=0.9875$ ), respectively (see SD5 $\dagger$ ). These confirm the electrode process is controlled by a diffusion process. On the other hand, diffusion of $\mathrm{Cu}$ (II) cations from the channels of the zeolite in carbon paste to the electrode surface controls the rate of the
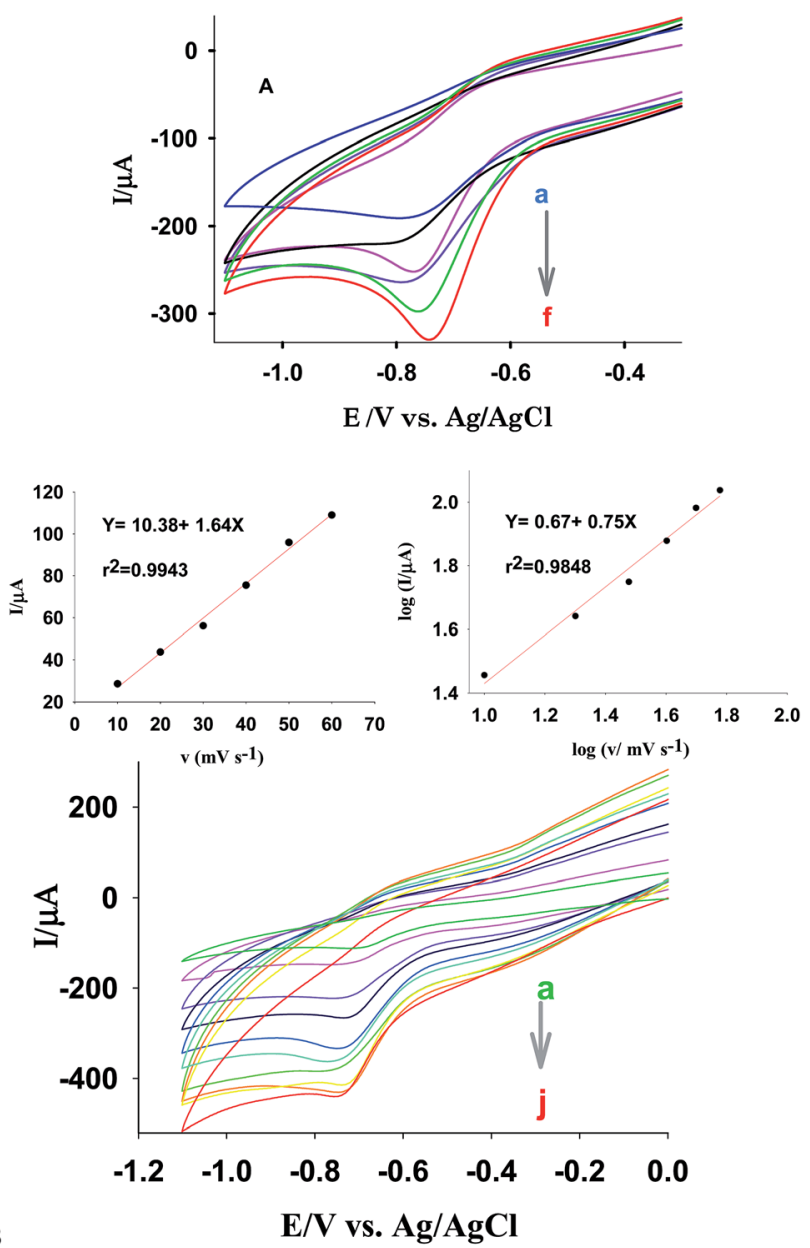

Fig. 3 CVs of $\mathrm{Cu}(\Perp)_{0.5}$ - CNP/CPE (with $20 \%$ w of the modifier) (A) in $0.4 \mathrm{~mol} \mathrm{~L}^{-1} \mathrm{NaCl}$ solution at various scan rates $0.4 \mathrm{~mol} \mathrm{~L}^{-1} \mathrm{NaCl}$ at scan rates of (a) 10, (b) 20, (c) 30, (d) 40, (e) 50 and (f) $60 \mathrm{mV} \mathrm{s}^{-1}$; (B) in $0.4 \mathrm{~mol} \mathrm{~L}^{-1} \mathrm{NaCl}+5 \times 10^{-3} \mathrm{~mol} \mathrm{~L}^{-1} \mathrm{MNZ}$ at different scan rates covering the range from 10 to $90 \mathrm{mV} \mathrm{s}^{-1}(\mathrm{a}-\mathrm{f})$, inset: typical plot of $I_{\mathrm{p}}$ versus potential scan rate in the range of 10 to $80 \mathrm{mV} \mathrm{s}^{-1}$. 

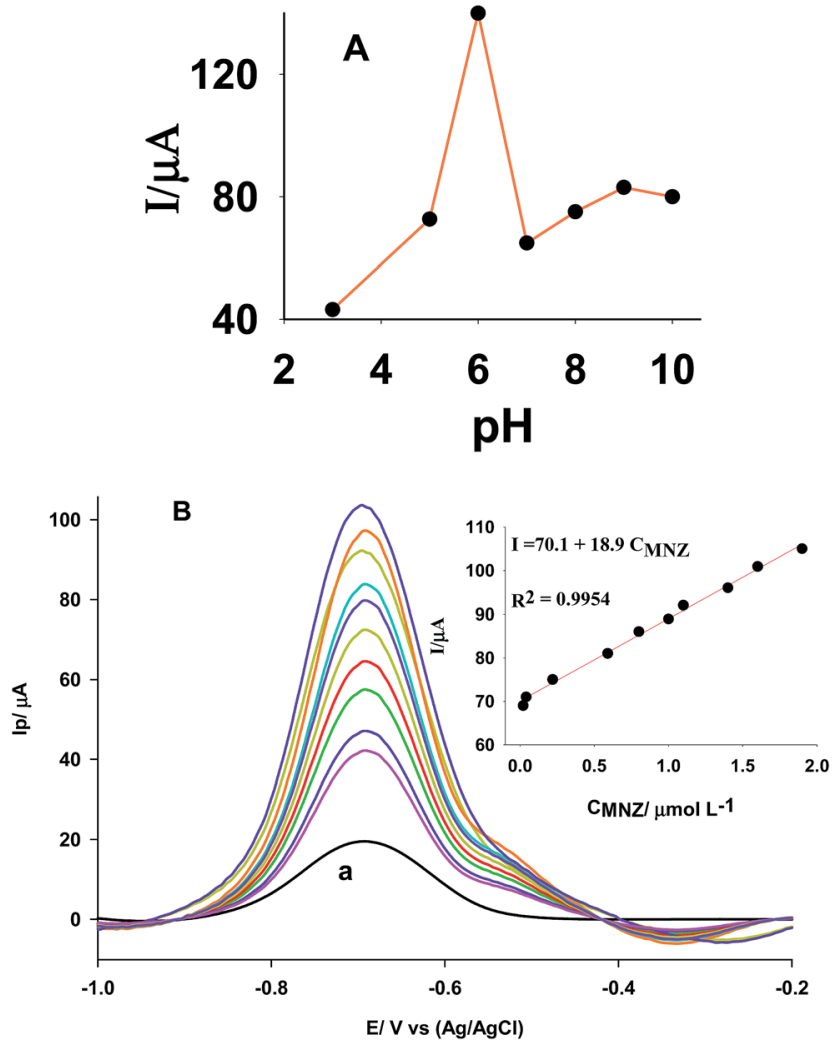

Fig. 4 (A) Effect of $\mathrm{pH}$ on the peak current of $\mathrm{Cu}(I)_{0.5}-\mathrm{CNP} / \mathrm{CPE}$ (with $20 \%$ w of the modifier) in $0.4 \mathrm{~mol} \mathrm{~L}^{-1} \mathrm{NaCl}+5 \times 10^{-3} \mathrm{~mol} \mathrm{~L}^{-1} \mathrm{MNZ}$ at scan rate of $70 \mathrm{mV} \mathrm{s}^{-1}$; (B) typical SqW voltammograms of $\mathrm{Cu}(I)_{0.5^{-}}$ CNP/CPE (with $20 \%$ w modifier) in $0.4 \mathrm{~mol} \mathrm{~L}^{-1} \mathrm{NaCl}$ at scan rates $70 \mathrm{mV} \mathrm{s}^{-1}$ containing different concentrations of MNZ ((a) in the absence of MNZ), inset: typical calibration curve, square wave conditions: step potential: $5 \mathrm{mV}$, amplitude: $55 \mathrm{mV}$, frequency: $25 \mathrm{~Hz}$.

electrochemical reaction. It has demonstrated that if the slope of $\log I_{\mathrm{p}}-\log \nu$ plot is 0.5 and 1.0, the electrode reaction is expected to be controlled by diffusion and surface confinement processes, respectively. ${ }^{\mathbf{1 9 - 2 1}}$

Similar observations were also obtained in the presence of MNZ (Fig. 3B). So, the linear behavior between $I_{\mathrm{p}}-\nu(y=10.38+$ $\left.1.65 x, r^{2}=0.9943\right)$ and $\log I_{\mathrm{p}}-\log \nu\left(y=0.67+0.75 x, r^{2}=0.9848\right)$ in the range of $10-60 \mathrm{mV} \mathrm{s}^{-1}$ confirm the electrode response is controlled by an adsorption process. On the other hand in these conditions, MNZ molecules are present at diffusion layer (or adsorbed at the electrode surface) and control electrochemical reaction of $\mathrm{Cu}$ (II) cations. While at higher scan rates $(70-160 \mathrm{mV}$ $\left.\mathrm{s}^{-1}\right)$ a linear response was observed for plot of $I_{\mathrm{p}}-\nu^{1 / 2}(y=99.6+$ $3.89 x, r^{2}=0.9928$ ), confirming a diffusion control process at these conditions. On the other hand, at such scan rate region diffusion of MNZ to the electrode-solution interface is controlling factor for the electrode behavior.

3.2.3. Effect of $\mathbf{p H}$. As shown in Fig. 4A, the best peak current was obtained at $\mathrm{pH} 6$ by $\mathrm{Cu}(\mathrm{II})_{0.5}-\mathrm{CNP} / \mathrm{CPE}$ (containing $20 \% \mathrm{w}$ of the modifier) in $0.4 \mathrm{~mol} \mathrm{~L}^{-1} \mathrm{NaCl}+5 \times 10^{-3} \mathrm{~mol} \mathrm{~L}^{-1}$ MNZ. It would be expected that higher peak current should be obtained at strong acidic pHs because of taking place higher extent of reactions (1) to (3) at such conditions. According the obtained results, it can be suggested that at strong acidic pHs MNZ molecules can be protonated $\left(\mathrm{p} K_{\mathrm{a}}: 2.4\right)$ and hence complexation of $\mathrm{MNZ}$ with $\mathrm{Cu}$ or $\mathrm{Cu}(\mathrm{I})$ species to be un-favored, causing to decrease in peak current as illustrated in section 3.2.1. At $\mathrm{pHs}>6$ exchanged $\mathrm{Cu}$ (II) present at the electrode surface may be precipitated as hydroxide, causing to decrease in peak current. It is worth mentioning that there is no considerable difference between peak current in phosphate and citrate buffers.

3.2.4. Characteristics of the electrode. The modified $\mathrm{Cu}(\mathrm{II})_{0.5}-\mathrm{CNP} / \mathrm{CPE}$ electrode was used for the quantitative determination of MNZ under the optimized conditions at SqW technique which some SqW voltammograms are shown in Fig. 4B. The linear relationship between $I_{\mathrm{p}} v s$. $C_{\mathrm{MNZ}}$ obtained in concentration range of $2.0 \times 10^{-8}$ to $1.6 \times 10^{-6} \mathrm{~mol} \mathrm{~L}^{-1} \mathrm{MNZ}$ $\left(I_{\mathrm{p}}=70.1+18.9 C_{\mathrm{MNZ}}, r^{2}=0.9954\right)$. A detection limit of $4.1 \times$ $10^{-9} \mathrm{~mol} \mathrm{~L}^{-1} \mathrm{MNZ}$ was estimated based on $3 S_{\mathrm{b}} / m$, where $S_{\mathrm{b}}$ is the standard deviation of the blank signal (10 replicates) and $m$ is calibration slope. $C_{\mathrm{LOQ}}$ can be estimated by $10 S_{\mathrm{b}} / m$ about $1.4 \times 10^{-8} \mathrm{~mol} \mathrm{~L}^{-1} \mathrm{MNZ}$.

Long term stability of the proposed electrode was investigated by taking its response in a period of 6 months. The electrode was stored in open air when not in use. Voltammetric measurements were performed every week during the mentioned period. The obtained peak currents in each case were averaged based on 5 replicates and the standard deviations compared by statistical $g$-test. The value of 0.0851 for $g_{\exp }$ was smaller than the critical value $\left(g_{0.05,5,24}=0.1656\right)$, indicating the electrode responses in the mentioned period affected by random errors and no considerable difference is present between the averages at $95 \%$ confidence interval.

Good repeatability of the electrode (within electrode variation) was evaluated by the small relative standard deviation of $1.5 \%$ in 10 replicate measurements on a single electrode. Similarly, good reproducibility of the electrodes was studied by comparing of the response of 4 similar independent electrodes (between electrode variations). Comparison of $g_{\exp }$ of 0.4485 with the critical value $\left(g_{0.05,5,4}=0.7212\right)$ confirms that the response of these electrodes have not significant difference at $0.95 \%$ confidence interval. In long term stability, repeatability and reproducibility experiments the optimized conditions were used $\left(0.4 \mathrm{~mol} \mathrm{~L}^{-1} \mathrm{NaCl}+0.005 \mathrm{~mol} \mathrm{~L}^{-1} \mathrm{MNZ}\right.$ at pH $5.520 \%$ $\mathrm{Cu}(\mathrm{II})_{0.5}$-CNP modifier, scan rate $70 \mathrm{mV} \mathrm{s}^{-1}$ ).

Table 2 Interference study for the determination MNZ under the optimized conditions $\left(C_{\mathrm{MNZ}}: 1.0 \times 10^{-6} \mathrm{~mol} \mathrm{~L}^{-1}\right)$

\begin{tabular}{lll}
\hline Species & $\begin{array}{l}C \\
\text { (Interf./MNZ) }\end{array}$ & $\begin{array}{l}\text { Interference } \\
\text { limit in literature }\end{array}$ \\
\hline $\mathrm{Mg}^{2+}$ & 150 & 50 \\
$\mathrm{~K}^{+}$ & 460 & 300 \\
$\mathrm{~Pb}^{2+}$ & 55 & 20 \\
$\mathrm{Zn}^{2+}$ & 60 & 50 \\
$\mathrm{Al}^{3+}$ & 85 & 20 \\
$\mathrm{Ca}^{2+}$ & 250 & 300 \\
$\mathrm{Ni}^{2+}$ & 250 & - \\
$\mathrm{Co}^{2+}$ & 350 & -
\end{tabular}


Table 3 Results of voltammetric determination of MNZ in some real samples

\begin{tabular}{|c|c|c|c|c|}
\hline MNZ samples & Company & Measured value $(n=3)$ & Standard values & $t_{\exp }$ \\
\hline \multirow[t]{3}{*}{ Tablet } & Tehran Chemie & $248.8 \pm 2.71 \mathrm{mg}$ per tablet & 250 & 0.76 \\
\hline & Alborz & $251.2 \pm 3.29 \mathrm{mg}$ per tablet & 250 & 0.61 \\
\hline & Abidie & $247.9 \pm 3.34 \mathrm{mg}$ per tablet & 250 & 1.08 \\
\hline Vaginal suppository & Behvazan & $0.75 \pm 0.02 \mathrm{~g} / 100 \mathrm{~g}$ & 0.75 & 0.91 \\
\hline Injection solution & Iran Samen & $498.4 \pm 6.47 \mathrm{mg} / 100 \mathrm{~mL}$ & 500 & 0.42 \\
\hline
\end{tabular}

Table 4 Comparison of the characteristics of the $\mathrm{Cu}\left({ }^{\prime \prime}\right)_{0.5}$ - CNP/CPE electrode with some previous works in determination of MNZ

\begin{tabular}{|c|c|c|c|c|}
\hline Electrode/modifier & Method & $\mathrm{LR}\left(\mathrm{mol} \mathrm{L}^{-1}\right)$ & $\mathrm{DL}\left(\mathrm{mol} \mathrm{L}^{-1}\right)$ & Ref. \\
\hline Coated GCE & $\mathrm{CV}$ & $7 \times 10^{-5}$ to $8 \times 10^{-4}$ & $2.3 \times 10^{-6}$ & 3 \\
\hline DNA/GCE & $\mathrm{CV}$ & $1 \times 10^{-7}$ to $6 \times 10^{-6}$ & $2 \times 10^{-9}$ & 7 \\
\hline $\mathrm{Au}$ electrode & CPP & $2 \times 10^{-5}$ to $8 \times 10^{-4}$ & $1.5 \times 10^{-7}$ & 22 \\
\hline 3D GNE & SWV & $1 \times 10^{-9}$ to $2 \times 10^{-6}$ & $1 \times 10^{-10}$ & 23 \\
\hline MIS-CPE & DPSV & $1 \times 10^{-6}$ to $1 \times 10^{-4}$ & $3.6 \times 10^{-9}$ & 24 \\
\hline Activated GCE & LSV & $2 \times 10^{-6}$ to $6 \times 10^{-4}$ & $1.1 \times 10^{-6}$ & 27 \\
\hline $\mathrm{Cu}(\mathrm{II})_{0.5}-\mathrm{CNP} / \mathrm{CPE}$ & $\mathrm{SqW}$ & $2 \times 10^{-8}$ to $1.6 \times 10^{-6}$ & $4.1 \times 10^{-9}$ & This work \\
\hline
\end{tabular}

Selectivity of the proposed method in the determination of MNZ was studied by measuring $\mathrm{MNZ}\left(1.0 \times 10^{-6} \mathrm{~mol} \mathrm{~L}^{-1}\right)$ in the presence of some various foreign species (see Table 2). Tolerance limit is the maximum concentration of foreign substances that caused relative error about $\pm 5 \%$. Hence, the constructed electrode can be used for determination of MNZ in the presence of used interfering species.

Practical applicability of the proposed electrode was also tested in determination of MNZ in some pharmaceutical samples. The standard addition method was applied in order to prevent any matrix effects (Table 3). Comparison of $t$-values with the critical value $\left(t_{0.05,2}=4.30\right)$ confirms there are no significant differences between the averages obtained by the modified electrode and reference values at 95\% confidence interval. Hence, the proposed electrode can be used for the determination of MNZ in real samples.

Table 4 shows the characteristics of the proposed modified electrode with respect to some previous modified electrodes in voltammetric determination of $\mathrm{MNZ}^{21-27}$ As shown, the proposed method has better linear range and detection limit than the most published works.

\section{Conclusion}

Modified carbon electrode with $\mathrm{Cu}(\mathrm{II})$-exchanged clinoptilolite showed good voltammetric response in the determination of metronidazole in aqueous solution. This is important because nitro group of MNZ which acts as an electroactive reducible center has shown poor reproducibility and sensitivity at the bare electrodes. The electrode process contains reduction of $\mathrm{Cu}(\mathrm{II}) / \mathrm{Cu}$ which produced $\mathrm{Cu}$ adsorbs $\mathrm{MNZ}$ to form $\mathrm{Cu}-\mathrm{MNZ}$ complex. In this complex, the internal redox reaction occurs and the obtained
$\mathrm{Cu}(\mathrm{II})-\mathrm{MNZ}$ can reduce at the electrode-solution interface, causing the peak current at more negative potentials. Hence, solution $\mathrm{pH}$ played an important role in formation of complex and ion exchange process at the electrode surface, so the best peak current obtained at $\mathrm{pH}$ 6. Corresponding peak current of reduction of $\mathrm{Cu}(\mathrm{II})-\mathrm{MNZ}$ is proportional to $C_{\mathrm{MNZ}}$ in solution and hence the proposed electrode can be used for quantitative determination of MNZ in aqueous solutions.

\section{References}

1 H. B. Ammar, M. Brahim, R. Abdelhédi and Y. Samet, Sep. Purif. Technol., 2016, 157, 9-16.

2 E. Roy, S. K. Maity, S. Patra, R. Madhuri and P. K. Sharma, RSC Adv., 2014, 4, 32881-32893.

3 C. Li, B. Zheng, T. Zhang, J. Zhao, Y. Gu, X. Yan, Y. Li, W. Liu, G. Feng and Zh. Zhang, RSC Adv., 2016, 6, 45202-45209.

4 J. Adamovics, J. Chromatogr., 1984, 309, 436-440.

5 M. Palomeque, J. A. Garć Bautista, J. V. Garc Mateo and J. Martínez Calatayud, Anal. Chim. Acta, 1999, 401, 229-236.

6 K. A. M. Attia, M. W. I. Nassar and M. B. El-Zeiny, Spectrochim. Acta, Part A, 2016, 154, 232-236.

7 X. Jiang and X. Lin, Bioelectrochem., 2006, 68, 206-212.

8 G. Yanga, F. Zhaoa and B. Zeng, Electrochim. Acta, 2014, 135, 154-160.

9 A. Bagheri-Ghomi and V. Ashayeri, Iran. J. Catal., 2012, 2(3), 135-140.

10 M. Shabani-Nooshabadi and F. Karimian-Taheri, RSC Adv., 2015, 5, 96601-96610.

11 S. Sharafzadeh and A. Nezamzadeh-Ejhieh, Electrochim. Acta, 2015, 184, 371-380.

12 A. T. Lawal and S. B. Adeloju, Talanta, 2013, 114, 191-203. 
13 Y. Zhuang, D. G. Zhang and H. Ju, Analyst, 2005, 130, 534540.

14 M. M. J. Treacy and J. B. Higgins, Elsevier, 2001, 184-189.

15 S. Aghabeygi, R. Kia Kojoori and H. Vakili Azad, Iran. J. Catal., 2016, 6(3), 275-279.

16 M. Inagaki, H. Orikasa and T. Morishita, RSC Adv., 2011, 1, 1620.

17 A. Nezamzadeh, M. Amini and H. Faghihian, Int. J. Electrochem. Sci., 2007, 2, 583-594.

18 J. Peng, C. Hou and X. Hu, Sens. Actuators, B, 2012, 169, 8187.

19 D. K. Gosser, Cyclic Voltammetry, Simulation and Analysis of Reaction Mechanisms, Wiley-VCH, New York, 1993.

20 E. G. D. Kul, M. Gumustas, B. Uslu and S. A. Ozkan, Talanta, 2010, 82, 286-295.
21 N. Erk, Anal. Biochem., 2003, 323, 48-53.

22 B. Rezaei and S. Damiri, Electrochim. Acta, 2010, 55, 18011808.

23 Y. B. Mollamahale, M. Ghorbani, M. Ghalkhani, M. Vossoughi and A. Dolati, Electrochim. Acta, 2013, 106, 288-292.

24 C. Hu, J. Deng, X. Xiao, X. Zhan, K. Huang, N. Xiao and S. Ju, Electrochim. Acta, 2015, 158, 298-305.

25 Y. Gu, X. Yan, W. Liu, C. Li, R. Chen, L. Tang, Zh. Zhang and M. Yang, Electrochim. Acta, 2015, 152, 108-116.

26 D. Chen, J. Deng, J. Liang, J. Xie, C. Hu and K. Huang, Sens. Actuators, B, 2013, 183, 594-600.

27 S. A. Ozkan, Y. Ozkan and Z. Senturk, J. Pharm. Biomed. Anal., 1998, 17, 299-305. 